\title{
Thatcher's Children, Blair's Babies, Political Socialization and Trickle-down Value Change: An Age, Period and Cohort Analysis
}

\author{
MARIA TERESA GRASSO, STEPHEN FARRALL, EMILY GRAY, COLIN HAY AND \\ WILL JENNINGS*
}

To what extent are new generations 'Thatcherite'? Using British Social Attitudes data for 1985-2012 and applying age-period-cohort analysis and generalized additive models, this article investigates whether Thatcher's Children hold more right-authoritarian political values compared to other political generations. The study further examines the extent to which the generation that came of age under New Labour - Blair's Babies shares these values. The findings for generation effects indicate that the later political generation is even more right-authoritarian, including with respect to attitudes to redistribution, welfare and crime. This view is supported by evidence of cohort effects. These results show that the legacy of Thatcherism for left-right and libertarian-authoritarian values is its long-term shaping of public opinion through political socialization.

Keywords: Thatcherism; New Right; political socialization; political generations; age, period and cohort analysis; social attitudes; Thatcher's Children

As early as January 1979, Stuart Hall, who coined the term 'Thatcherism', wrote: 'No one seriously concerned with political strategies in the current situation can now afford to ignore the "swing to the Right." That year, as was later shown, ${ }^{1}$ marked the high point of the British electorate's rightward movement - and the 'sea change' (as Jim Callaghan called it) in public opinion that was marked by the election of the Thatcher government. For many, Thatcher's 'authoritarian populism' captured the nation's anxious mood in the economic crisis of the mid-to-late 1970s in the aftermath of the upswing in industrial militancy and the cultural radicalism of the 'permissive society' of the 1960s and early 1970s. ${ }^{2}$ The Left was divided in Britain and unable to exploit the social liberalism of the previous decade to articulate a relevant progressive political discourse. Thatcher was still in office when Ivor Crewe $^{3}$ posed the question of whether the British electorate had 'become Thatcherite'. Subsequent studies analysed Thatcher's Children and the extent to which this generation was more right wing relative to predecessors, and found mixed evidence. ${ }^{4}$

* University of Sheffield, Department of Politics (email: m.grasso@ sheffield.ac.uk); University of Sheffield, School of Law (email: s.farrall@sheffield.ac.uk); University of Sheffield, School of Law (email: emily. gray@sheffield.ac.uk); Sciences Po, Paris, Centre d'Études Européennes (email: colin.hay@sciencespo.fr); University of Southampton, Department of Politics and International Relations (email: w.j.jennings@soton.ac.uk). The authors would like to thank Stephen Fisher, Charles Pattie and James Tilley as well as three anonymous reviewers and Rob Johns for comments and suggestions. We would also like to acknowledge the support of the UK Economic and Social Research Council (Award no: ES/K006398/1). The usual disclaimers apply. Data replication sets are available at http://dataverse.harvard.edu/dataverse/BJPolS.

1 Bartle, Dellepiane-Avellaneda, and Stimson 2011.

2 Hay 1996.

3 Crewe 1988.

4 See, e.g., Heath and Park 1997; Russell, Johnston, and Pattie 1992; Tilley 2002. 
In this article we examine the question of political generations by analysing the extent to which a political context marked by a right-authoritarian zeitgeist influenced the values of new cohorts. While this wider theoretical question is applicable to other comparative contexts such as the United States under Reagan and the rise of the Moral Majority, in this article we use British data since the prolonged period of Conservative rule in Britain between 1979 and 1997 provides an excellent test case for examining the theory of political generations and formative experiences. Normally we would expect younger generations to be more leftist and liberal than older generations. Therefore the protracted period with the Conservative Party in office allows us to test whether younger cohorts coming of age in this political context came to adopt political attitudes in line with those of this party at a greater rate than would be expected given their age. Further, our investigation builds on this traditional question by examining whether the generation that came of age under New Labour, 'Blair's Babies', can be better identified as 'Thatcher's Grandchildren', in reinforcing the rightward shift in social values that had occurred under the previous generation.

We postulate a "trickle-down' ${ }^{5}$ theory of social change: during the first phase of Conservative government (normative neoliberalism) there was deeper ideological contestation, while in the second phase (normalized neoliberalism) even political opponents and rival partisans had internalized its market precepts as 'the rules of the game'. The 1980s were marked by a concentrated political shift towards neoliberal market economies in many Western democracies. ${ }^{6}$ The rise of the New Right signalled a rightward shift in opinion in the United States, United Kingdom and other Anglo-American democracies in the 1980s. As such, we seek to gauge whether those who came of age under Thatcher and subsequent prime ministers are more politically conservative than those who came of age earlier, when such values were more frequently contested.

In short, the question addressed in this article is: To what extent did the generations coming of age in the protracted period of Conservative government come to exhibit more conservative values? What were the differences between the generation that came of age in the first phase (during Thatcher's time in office) relative to the second phase (after she left office, during the time of New Labour)? We theorize that 'Thatcher's Children' may be less Thatcherite than 'Blair's Babies', as Thatcherite values became entrenched across society - as signalled by New Labour's emergence - after she left office. ${ }^{7}$

The remainder of the article is organized as follows. We first discuss theories of generational replacement and value change and develop our hypotheses. We then discuss the data and methods used in this study of attitudinal change in Britain: specifically, a newly combined longitudinal dataset built from repeated cross-sectional sweeps of the British Social Attitudes survey for the period from 1985 to $2012 .{ }^{8}$ These are used to identify and isolate the different effects of age, period and cohort on social values. We next present our results concerning the degree to which generations socialized during and after Thatcher was prime minister differ in their attitudes to redistribution, welfare and authority. Finally, we conclude with a discussion of the implications of these findings for our understanding of the Thatcher years and their legacy, and reflect on their wider significance for the study of the evolution of social and political attitudes and long-term processes of socialization.

${ }^{5}$ This term has been employed in popular political commentary/critiques, particularly of President Reagan's administration and other laissez-faire capitalist economies. The concept originated in the United States when Democratic presidential candidate William Bryan referred to the idea in a speech in 1896 in which he compared promoting economic prosperity via either 'top-down' or 'bottom-up' strategies (Sowell 2012).

${ }^{6}$ Braedley and Luxton 2010; Duménil and Lévy 2011; Kotz 2015.

${ }^{7}$ Hay 2004.

${ }^{8}$ See Jennings et al. 2015. 


\section{POLITICAL GENERATIONS}

Generational theories share the idea that values are formed early on, are influenced by the specific historical and political contexts within which each new cohort of citizens is socialized, and remain stable throughout the life course, so that aggregate value change occurs as older cohorts with certain value sets die and are replaced by younger cohorts with different values. ${ }^{9}$ One such type of account is modernization theory. ${ }^{10}$ However, while modernization theory allows for some short-term shifts in values, the theory suggests that social liberalism should become increasingly widespread at the aggregate level, given underlying secular trends. ${ }^{11}$ In contrast, political generations theory takes a historicized perspective that emphasizes the importance of political events and experiences taking place during the impressionable 'formative years' to different cohorts. ${ }^{12}$ According to this line of thinking, it is not so much affluence and security in childhood that shapes the values and political commitments of new cohorts, but rather the political experiences and historical events occurring during one's young adulthood. Various studies have shown that diverse political contexts can produce generations with distinct value sets and patterns of behaviour. ${ }^{13}$ Critical historical moments such as the worldwide student protests of 1968 or the fall of the Berlin Wall, a prolonged period during which the same party holds power, and other types of major external events during a cohort's coming of age are understood to explain why socialization in diverse political contexts creates distinct 'political generations'. While members of a given political generation are divided by social cleavages such as gender and class (Mannheim ${ }^{14}$ calls these 'generation units'), nonetheless, as a generation, they are understood to share the same values and conceptions of the world because they emerged from the same temporal/spatial location. Mannheim ${ }^{15}$ thus likens generations to social classes arising from distinct positions in the economic or material realm. ${ }^{16}$ While some studies of macro-level preferences have shown how publics react thermostatically to the government of the day, ${ }^{17}$ others have argued that parties in government are able to shape the preferences of the electorate ${ }^{18}$ which would be consistent with the effect of socialization on political values during certain periods.

\section{'THATCHER'S CHILDREN'}

Gamble $^{19}$ characterizes Thatcherism as a marriage of 'the free economy and the strong state' - a flexible synthesis, in other words, of market liberalization (support for a smaller state, deregulation of financial markets, privatization of publicly owned industries and assets, the sale of council houses) and social conservatism with a strengthened law and order agenda

9 Erikson and Stoker 2011; Mannheim 1928.

10 Inglehart 1977, 1990.

11 Inglehart 1977, 1990; Inglehart and Welzel 2005.

12 Mannheim 1928.

13 Bartels and Jackman 2014; Grasso 2011, 2014, 2016; Neundorf and Niemi 2014; Tilley 2002; Tilley and Evans 2014.

14 Mannheim 1928.

15 Mannheim 1928.

16 While inter- and not intra-generational differences are the focus of this article, Mannheim (1928) also recognizes the latter in his concept of 'generation units'. It is thus important to control, as we do in this article, for a wide variety of factors that could result in inter-generational (historical) differences that are not necessarily linked to political socialization, that is, historical experiences.

17 Bartle, Dellepiane-Avellaneda, and Stimson 2011; Erikson, Mackuen, and Stimson 2002, and Wlezien 1995.

18 Curtice and Fisher 2003; Dunleavy and Ward 1981.

19 Gamble 1988. 
(Clause 28, extending police powers, facing down trade unions as 'the enemy within', a tougher rhetorical stance on sentencing, Cold War rearmament). In this conception, Thatcherism sought to establish a hegemonic project involving ideology, economics and politics, a politics of support and a politics of power'. ${ }^{20}$ Hall saw Thatcherism as more than simply 'the corresponding political bedfellow of a period of capitalist recession' but as a dramatic rupture from the politics of the social-democratic post-war consensus. ${ }^{21}$ Gilroy and Simm pointed out how the main innovation with respect to 'law and order' during the Thatcher governments was to politicize and present the repressive state institutions as necessary instruments in the fight against certain 'subversive' elements in society and winning support for this from large sections, if not the majority, of the British public. ${ }^{22}$ The politicization of 'law and order' was a crucial break brought forth by the Thatcher governments, and the appeal of populism was understood as a key reason why almost a third of trade unionists voted for the Conservatives in May 1979. ${ }^{23}$ Thatcher's emphasis on the politics of confrontation and pitting different social sectors against each other to garner support through 'divide-and-rule' strategies was most commonly associated with the reaction to the inner-city riots in 1981 and the Miners' Strike in 1984-85. In many ways, the Thatcher governments of this period were quite distinctive and presented themselves as breaking from the post-war consensus. The Conservatives were in office continuously for eighteen years between 1979 and 1997 (under Margaret Thatcher until 1990, and then under John Major), the longest unbroken period of rule by one party in the UK since 1830 . These factors combined would suggest a strong influence on the values of young people coming of age in this political context.

Early research on the impact of Thatcherism on British public attitudes began by looking at straightforward, over-time change. For example, Crewe ${ }^{24}$ explored whether the electorate had become more focused on self-reliance, and found decreasing enthusiasm for this idea. The turning point in the research on the attitudinal impact of Thatcherism came with Russell et al.'s ${ }^{25}$ pioneering study, which was the first to examine the political socialization of 'Thatcher's Children' and generational effects. They showed that while ageing had a tendency to increase Conservative identification, the formative experiences of electoral generations resulted in persistent cohort differences. Russell et al. ${ }^{26}$ concluded that socialization during Thatcher's term in office meant that first-time voters in the 1979 and 1987 elections were more likely to support the Conservatives than would have been expected given their age. This study showed that examining the imprint on the youngest generations and the impact of political socialization was an important aspect to consider when analysing whether Thatcher had changed Britain's values.

Later, Heath and Park ${ }^{27}$ showed some signs of a Thatcherite generational shift, finding evidence that the 1980s generation was more materialistic than previous generations. Examining cohort differences in British Election Study data, Tilley ${ }^{28}$ showed that the younger cohorts' tendency to move away from the Conservatives was reversed in the 1980s and 1990s. Later, Tilley and Heath ${ }^{29}$ showed how Thatcher was able to arrest the decline in feelings of national

20 Gamble 1988, 223.

21 Hall 1979.

22 Gilroy and Simm 1985.

23 Hobsbawm 1979; Farrall and Hay 2014; Farrall, Jackson and Gray 2009.

24 Crewe 1989.

25 Russell, Johnston, and Pattie 1992.

26 Russell, Johnston, and Pattie 1992.

27 Heath and Park 1997.

28 Tilley 2002.

29 Tilley and Heath 2007. 
pride and the trend towards more liberal young generations. ${ }^{30}$ Tilley and Evans ${ }^{31}$ recently showed how the generations coming of age in periods of Conservative ascendancy (the 1930s, 1950 s and 1980s) were all more likely to support this party.

It was not until the late 1990s that aggregate studies of public opinion began to show a Thatcherite shift, supporting the idea of a process of underlying generational replacement at play. Curtice and Jowell ${ }^{32}$ provide evidence that between 1985 and 1996 fewer people agreed that government should provide healthcare, pensions, control prices, help industry grow, help poor families send their children to university, provide shelter for the poor, reduce inequality, provide jobs or help the unemployed. Evidence from the British Social Attitudes Survey showed that the proportion of the electorate agreeing that 'governments ought to redistribute income' had fallen from 45 per cent in 1987 to 36 per cent in 2009, while the proportion saying 'government ought to spend more on benefits' fell from 55 per cent in 1987 to 27 per cent in 2009. ${ }^{33}$

\section{'THATCHER'S GRANDCHILDREN'?}

Since Major did not set out to openly challenge Thatcher's policies, we expect that the socialization experiences of young people coming of age during his time in office should not have differed substantially from those coming of age under Thatcher's governments. The emergence of New Labour under Tony Blair signalled that while it was internally divided, Labour had also moved closer to the Thatcher agenda primarily as the result of an ideological move dictated by the party leadership. ${ }^{34}$ Particularly from the inception of New Labour in 1994, all three main parties were converging on a recognizably Thatcher-influenced 'middle ground', so that the primacy of the market became the accepted wisdom ${ }^{35}$ and Thatcherite polices were consolidated by Blair. ${ }^{36}$ Since New Labour has come to be widely understood as 'Thatcherism by another name' ${ }^{37}$ and its values even less contested than when she was in office, we test the proposition that the values of the generation coming of age between 1997 and 2010 will be even more right wing and authoritarian than those of previous generations. Based on the discussion above, we test the following two hypotheses:

HYPOTHESIS 1: The cohort that came of age between 1979 and 1996 will be more right wing and more authoritarian than cohorts that came of age prior to this prolonged period of Conservative rule.

HYPOTHESIS 2: The cohort that came of age under New Labour between 1997 and 2010 will be more right wing and more authoritarian than cohorts that came of age before them.

\section{DATA AND METHODS}

The analysis in this article relies on British Social Attitudes survey data for the period between 1985 and 2012. These are repeated cross-sectional surveys in which respondents were asked the

30 Tilley 2005.

31 Tilley and Evans 2014.

32 Curtice and Jowell 1997.

33 Curtice 2010.

34 Evans and Tilley 2012.

35 Heffernan 2000.

36 Curtice 2009; Curtice and Fisher 2003; Farrall and Hay 2014.

37 Coates 2005; Faucher-King and Le Gales 2010; Hay 1996; Shaw 2008. 
same attitudinal and other questions at different points in time. The dataset was constructed specifically for the purposes of this type of analysis. ${ }^{38}$ It thus provides rich individual-level data on social attitudes and political values relevant to Thatcherism as well as all the necessary control variables over a sufficiently long time span to separate age, period and cohort effects.

\section{Dependent Variables}

While most studies on the generation politically socialized under Thatcher have examined partisanship or just a few available indicators of left-right and libertarian-authoritarian values, in this study we examine nine different indicators of right-authoritarian values side by side. In each case the survey item has been recoded so that a value of 1 indicates agreement with the Thatcherite position and a value of 0 indicates disagreement. This allows direct comparisons across indicators, and means that in the results an increasing trend suggests greater agreement with the Thatcherite stance in the same way across all indicators. ${ }^{39}$ The variables tap into both left-right economic and libertarian-authoritarian social values. More specifically, the following nine dependent variables are analysed in this study:

1. What do you think about the income gap between the rich and the poor in the UK today? ( 1 = About Right, Too Small; $0=$ Too Large)

2. Government should redistribute from the better off to the less well off. $(1=$ Disagree, Strongly Disagree; $0=$ Neither, Agree, Strongly Agree)

3. Government should spend more money on the poor even if it leads to higher taxes. $(1=$ Disagree, Strongly Disagree; $0=$ Neither, Agree, Strongly Agree).

4. Opinions differ about the level of benefits for the unemployed. Which of these best reflects your opinion?

( $1=$ Benefits are too high and discourage people from finding jobs; $0=$ Other response categories i.e. Benefits are too low and cause hardship, Neither, Both cause hardship, Some people benefit, Some people suffer, About right, Other)

5. The unemployed could find a job if they wanted to. $(1=$ Agree, Strongly Agree; $0=$ Neither, Disagree, Strongly Disagree)

6. People should learn to stand on their own feet. ( 1 = Agree, Strongly Agree; $0=$ Neither, Disagree, Strongly Disagree)

7. The death penalty is appropriate for some crimes. ( 1 = Agree, Strongly Agree; $0=$ Neither, Disagree, Strongly Disagree)

8. People who break the law should be given stiffer sentences. $(1=$ Agree, Strongly Agree; $0=$ Neither, Disagree, Strongly Disagree)

9. Schools should teach children to obey authority. $(1=$ Agree, Strongly Agree; $0=$ Neither, Disagree, Strongly Disagree $)$

\section{AGE-PERIOD-COHORT MODELLING STRATEGY}

Generational theories, such as those discussed earlier, tend to argue that the context of one's socialization is the most important factor for understanding differences in values relative to age or period effects. However, research on cohort effects needs to address the potentially confounding influences of age and period effects when estimating the models. Age effects suggest that values change as individuals age, and indeed research has found that older people

38 Jennings et al. 2015.

39 While we run logistic models on dummy dependent variables for the age-period-cohort models, where possible, we also ran the models as ordered logistic regressions on the full scale as robustness checks. 
tend to be more conservative than younger people. Moreover, certain periods signal a rightward shift for all individuals in society, such as the period of Thatcher's ascendancy in Britain. Therefore in order to identify cohort effects, we also need to control for both age and period, or year of survey, in our models. This issue is known as the age-period-cohort identification problem' in the literature. It emerges since the three effects are in a linear relationship with each other. As soon as we know two values, we simultaneously know the third:

$$
\text { Year of Birth }=\text { Year }- \text { Age }
$$

In order to 'identify' the model and capture net effects it is necessary to apply certain restrictions. This methodological hurdle has meant that a rich statistical literature has emerged over the years presenting methods to 'solve' the identification problem. ${ }^{40}$ In this article, we follow the method presented in Grasso, ${ }^{41}$ which consists of applying generalized additive models (GAMs) to plot the identified, smoothed cohort effect as well as testing for intergenerational differences using constrained age-period-cohort models and post-estimation Wald tests. Since the data employed are from a single country, we do not need to apply generalized additive mixed models (GAMMs) in this context but can safely rely on nonhierarchical generalized additive models (GAMs), using the continuous year of birth variable to plot the smoothed cohort effect in order to overcome the identification problem. Moreover, to test for cohort differences we apply Wald tests after estimating age-period-cohort regression models using a categorized cohort variable, reflecting the theoretical distinctions based on the historical period of socialization.

The GAMs allow us to plot the nonlinear smoothed cohort effect since year of birth is estimated as smoothly changing. There are different smoothing functions that could be applied; smoothing splines are used here, and the software package selected the smoothing parameter by generalized cross-validation. This allows us to plot the non-parametric smoothed curve for the effect of year of birth. ${ }^{42}$ The utility of the application of the GAMs is that it permits us to visually check whether cohort effects are what we would expect based on the categorized generations variable from the age-period-cohort (APC) models. Arriving at the same results using two different methods and applying different types of restrictions gives us greater confidence in our results. This combined method for dealing with the identification problem is particularly appropriate here, as it has been developed specifically for research questions examining political generations with repeated cross-sectional attitudinal data, which are typical in political science. ${ }^{43}$ GAMs are particularly useful for examining the non-linear components of generational effects. Other approaches, such as the intrinsic estimator (IE) and hierarchical APC (HAPC) models developed in demography and epidemiology, are not employed here since they are less suited to the current type of data structure and research questions. ${ }^{44}$ Simulation studies have shown that these methods run the risk of incorrectly attributing trends in age, period or cohort to the other two terms. ${ }^{45}$ Moreover, Luo shows that IE relies on arbitrary and unjustified constraints. ${ }^{46}$ However, we combine constrained APC models and GAMs, which allows us to

\footnotetext{
40 See, for example, the special symposium in 2014 in Electoral Studies for recent advances in political science. See also Neundorf and Niemi 2014.

41 Grasso 2014.

42 Grasso 2011, 2014; Neundorf 2010; Shorrocks 2016; Tilley 2001, 2002, 2003.

43 Grasso 2014.

44 Yang and Land 2006; Yang and Land 2008; Yang et al. 2008.

45 Bell and Jones 2014a; Bell and Jones 2014b.

46 Luo 2013.
} 
TABLE $1 \quad$ Political Generations

\begin{tabular}{lccccc}
\hline \hline & $\begin{array}{c}\text { Pre-consensus } \\
\text { generation }\end{array}$ & $\begin{array}{c}\text { Early consensus } \\
\text { generation }\end{array}$ & $\begin{array}{c}\text { Wilson/Callaghan's } \\
\text { Children* }\end{array}$ & $\begin{array}{c}\text { Thatcher's } \\
\text { Children** }\end{array}$ & $\begin{array}{c}\text { Blair's } \\
\text { Babies*** }\end{array}$ \\
\hline $\begin{array}{l}\text { Formative } \\
\text { period }\end{array}$ & $1930-1944$ & $1945-1964$ & $1965-1978$ & $1979-1996$ & $1997-2010$ \\
$\begin{array}{l}\text { Year of } \\
\text { birth }\end{array}$ & $1910-1924$ & $1925-1944$ & $1945-1958$ & $1959-1976$ & $1977-1990$ \\
$\begin{array}{l}\text { Total } N \\
\%\end{array}$ & 8,435 & 23,181 & 21,653 & 27,527 & 6,980 \\
\hline \hline
\end{tabular}

${ }^{*}$ This period includes the Conservative Heath government of 1970-1974.

${ }^{* *}$ This period also includes Major's period in office between 1990 and 1997.

*** This period includes the Blair and Brown governments.

clearly test our hypotheses by applying the theoretically derived cohort groupings as well as checking the results for robustness.

Given that we are interested in cohort differences, year of birth is the main independent variable. This ranges from 1910 to 1990 . The idea of a 'Thatcher effect' implies that the generations socialized during the period of her ascendancy will be particularly rightauthoritarian. The key period of socialization will largely depend on the mechanism implied in theory. ${ }^{47}$ Given that here we are examining the formation of political attitudes as a result of the ascendancy of a party in government, we would expect that socialization should occur from the mid-teens to the mid-to-late twenties. We use the method presented in Grasso ${ }^{48}$ to assign individuals to different political generations based on the historical phase in which they spent the majority of their formative years. As such, we define Thatcher's Children as those born between 1959 and 1976 and coming of age in the protracted period of Conservative rule between 1979 and 1996 (we include 1997 in the following period). Descriptions of the political generations analysed in this study are presented in Table 1.

This method of categorizing generations has the advantage that it emphasizes the historical period of a generation's socialization. The years of birth of the political generations are then derived from this information. We include the categorized political generations variable in the APC models in order to (1) cross-check the robustness of the results from the GAMs and (2) use Wald tests to test for cohort differences. In the GAMs we use the continuous year of birth variable to derive the smoothed cohort effects. In addition to year of birth/cohort, we also include age and period to identify the APC models. The description of variables henceforth applies to both the GAMs and APC models. Age is coded as a three-level factor: (1) thirty-four years and under, (2) thirty-five to fifty-nine years or (3) sixty years and over. Year of survey is included as a continuous variable. To test the robustness of the cohort effects, we ran the APC models with a number of alternative configurations of age and period.

\section{Other Variables}

We control for gender as well as education level, marital status, employment status, household income, whether or not the respondent attended private school, home ownership, union

47 Bartels and Jackman 2014; Inglehart 1977, 1990.

48 Grasso 2014. 


\begin{tabular}{lcccc}
\hline \hline & Mean & SD & Min & Max \\
\hline Dependent variables & & & & \\
(1) Income gaps too small or about right & 0.18 & 0.39 & 0 & 1 \\
(2) Disagree/strongly disagree: Government should redistribute & 0.34 & 0.47 & 0 & 1 \\
(3) Disagree/strongly disagree: Government should spend more on poor & 0.28 & 0.45 & 0 & 1 \\
(4) Benefits too high and discourage job search & 0.43 & 0.50 & 0 & 1 \\
(5) Unemployed could find job if they wanted to & 0.55 & 0.50 & 0 & 1 \\
(6) People should learn to stand on their own two feet & 0.42 & 0.49 & 0 & 1 \\
(7) Death penalty is appropriate for certain crimes & 0.61 & 0.49 & 0 & 1 \\
(8) Stiffer sentences for breaking the law & 0.80 & 0.40 & 0 & 1 \\
(9) Children should be taught to obey authority & 0.84 & 0.36 & 0 & 1 \\
Independent variables/controls & & & & \\
Political generations & 3.02 & 1.13 & 1 & 5 \\
Age groups & 2.03 & 0.75 & 1 & 3 \\
Year of survey & 1999.52 & 8.16 & 1983 & 2012 \\
Gender (male) & 0.44 & 0.50 & 0 & 1 \\
Education 19 years+ & 0.18 & 0.38 & 0 & 1 \\
Marital status & 1.60 & 0.78 & 1 & 3 \\
Employment status & 3.10 & 2.15 & 1 & 7 \\
Household income & 1.83 & 0.71 & 1 & 3 \\
Attended private school & 0.11 & 0.32 & 0 & 1 \\
Owns house & 0.69 & 0.46 & 0 & 1 \\
Union member & 0.22 & 0.41 & 0 & 1 \\
Social class & 3.34 & 1.32 & 1 & 6 \\
Conservative Party identification & 0.31 & 0.46 & 0 & 1 \\
\hline
\end{tabular}

membership and Conservative Party identification. In each case we use the most detailed measures available in the over-time longitudinal file. ${ }^{49}$ Descriptive statistics for all these variables are presented in Table 2.

Other than generation, younger age and higher education levels tend to be linked to greater liberalism. ${ }^{50}$ Younger cohorts are more likely to be highly educated and therefore more liberal than older cohorts. Modernization theorists argue that the expansion of education leads to greater liberalism among younger cohorts and therefore society as a whole through intergenerational replacement. As such, controlling for education and student status should allow us to capture the generational differences resulting from socialization as opposed to differences that can be attributed to other sorts of characteristics that should make younger cohorts more socially liberal. ${ }^{51}$ While modernization theory implies that the shift from materialist to postmaterialist values primarily occurs due to cohort replacement over time, in this way we can also control for some compositional changes.

Controls for marital status (married, previously married or single/never married) and employment status (full-time employment, part-time employment, unemployed/waiting for work, retired, student, taking care of the home or other employment situation) are included to

49 Jennings et al. 2015.

50 Evans and De Graaf 1996.

51 Grasso 2013; Grasso and Giugni 2013; Grasso and Giugni 2016a; Grasso and Giugni 2016b; Giugni and Grasso 2015 b. 
account for aspects of social ageing and structural position. ${ }^{52}$ They also deal with the issue that married people tend to be more conservative but that younger generations are less likely to settle into conventional family arrangements than previous generations. Moreover, since some of the items pertain to unemployment benefits, it is necessary to control for whether someone is seeking work. Students and women are also generally more liberal groups, whereas those retired from employment tend to be more conservative; as such, including gender and employment status in the models represent helpful controls.

Class is an important variable for understanding social differences in political values. In Britain, the middle classes have traditionally tended to associate with the Conservative Party, whereas the working classes have tended to support Labour. This picture has become more complex with class dealignment and the waning relevance of values concerning inequality and redistribution in political discourse, which traditionally translated class divisions into party choice. ${ }^{53}$ In any case, we would expect individuals in the middle class to be generally more likely to hold right-wing economic values, ${ }^{54}$ though the picture for authoritarianism is less clear. We also include three additional measures of privilege and social status - household income (low, mid, high), whether the respondent attended private school and home ownership - since more privileged individuals are more likely to defend inequality for obvious reasons, and this might be reflected in the composition of different cohorts. We also include controls for union membership and Conservative Party identification in order to address compositional differences between cohorts.

\section{ANALYSIS}

First we estimate APC models with our categorized cohort variable (as presented in Table 1). Next, in order to formally test whether certain political generations are more Thatcherite than others, we ran Wald tests. While the APC logistic regression models presented in Table 3 allow us to see whether differences between each cohort included in the model and the reference category ('Wilson/Callaghan's Children') are significant, Wald tests allow us to test for coefficient differences between the cohort categories included in the model. The results for the Wald tests are presented in Table 4.

While the controls generally exhibit the expected effects, gender does not have a consistent effect on either economic or social values. As expected, married individuals are more conservative than both previously married and single individuals. The same is true of individuals in full-time employment relative to all the other employment categories. As expected, individuals in the higher income categories are more Thatcherite with respect to redistribution, inequality, benefits and attitudes towards the unemployed. However, they are also less authoritarian than those with lower incomes. Having a private education is associated with being more Thatcherite with respect to redistribution and inequality. However, it also linked with being less likely to agree with the negative sentiments about benefits and the unemployed, and with being less authoritarian. As expected, home ownership tends to predict Thatcherism as (unsurprisingly) does party identification, whereas union membership decreases the likelihood that one will agree with Thatcherite values.

Class is an interesting variable. Compared to the middle class, all the other classes are less likely to agree that the income gap is too small or about right. The working class is more likely

\footnotetext{
52 Dunn, Grasso, and Saunders 2014; Giugni and Grasso 2015a; Giugni and Grasso 2016; Saunders et al. 2012.

53 Evans and Tilley 2012.

54 Dunleavy's sectoral cleavage suggests public vs. private sector differences are likely to differentiate the political values of the middle classes.
} 
TABLE 3 APC Models: Right-Authoritarian Values

\begin{tabular}{|c|c|c|c|c|c|c|c|c|c|}
\hline & $\begin{array}{l}\text { (1) } \\
\text { Income gap in } \\
\text { society is too } \\
\text { small or about } \\
\text { right }\end{array}$ & $\begin{array}{c}\text { Disagree/strongly } \\
\text { disagree: } \\
\text { Government } \\
\text { should redistribute }\end{array}$ & $\begin{array}{c}\text { Disagree/strongly } \\
\text { disagree: Government } \\
\text { should spend more to } \\
\text { help poor }\end{array}$ & $\begin{array}{l}\text { Benefits too } \\
\text { high and } \\
\text { discourage } \\
\text { job search }\end{array}$ & $\begin{array}{l}\text { Unemployed } \\
\text { could find a } \\
\text { job if they } \\
\text { wanted }\end{array}$ & $\begin{array}{l}\text { People should } \\
\text { learn to stand on } \\
\text { their own two } \\
\text { feet }\end{array}$ & $\begin{array}{l}\text { Death penalty } \\
\text { is appropriate } \\
\text { for certain } \\
\text { crimes }\end{array}$ & $\begin{array}{c}(8) \\
\text { Stiffer } \\
\text { sentences } \\
\text { for } \\
\text { breaking } \\
\text { the law }\end{array}$ & $\begin{array}{c}\text { (9) } \\
\text { Children } \\
\text { should be } \\
\text { taught to obey } \\
\text { authority }\end{array}$ \\
\hline \multicolumn{10}{|c|}{ Political generations (ref.: Wilson/Callaghan's Children) } \\
\hline Pre-consensus generation & $\begin{array}{l}0.30 * * * \\
(0.09)\end{array}$ & $\begin{array}{c}0.13 * \\
(0.06)\end{array}$ & $\begin{array}{c}0.03 \\
(0.08)\end{array}$ & $\begin{array}{l}0.52^{* * * *} \\
(0.06)\end{array}$ & $\begin{array}{l}0.24 * * * \\
(0.06)\end{array}$ & $\begin{array}{l}0.87^{* * *} \\
(0.06)\end{array}$ & $\begin{array}{c}0.10 \\
(0.06)\end{array}$ & $\begin{array}{l}0.55 * * * \\
(0.08)\end{array}$ & $\begin{array}{l}1.20 * * * \\
(0.10)\end{array}$ \\
\hline Early consensus generation & $\begin{array}{l}0.14 * * \\
(0.05)\end{array}$ & $\begin{array}{l}0.14 * * * \\
(0.04)\end{array}$ & $\begin{array}{l}0.04 \\
(0.05)\end{array}$ & $\begin{array}{l}0.24 * * * \\
(0.04)\end{array}$ & $\begin{array}{l}0.17 * * * \\
(0.04)\end{array}$ & $\begin{array}{l}0.44 * * * \\
(0.04)\end{array}$ & $\begin{array}{c}0.09 * \\
(0.04)\end{array}$ & $\begin{array}{l}0.27 * * * \\
(0.05)\end{array}$ & $\begin{array}{l}0.56^{* * * *} \\
(0.05)\end{array}$ \\
\hline Thatcher's Children & $\begin{array}{l}0.27 * * * \\
(0.05)\end{array}$ & $\begin{array}{l}0.09 * * \\
(0.03)\end{array}$ & $\begin{array}{l}0.35^{* * * *} \\
(0.04)\end{array}$ & $\begin{array}{l}0.15^{*} * * \\
(0.03)\end{array}$ & $\begin{array}{l}0.19 * * * \\
(0.04)\end{array}$ & $\begin{array}{l}0.11^{* *} \\
(0.04)\end{array}$ & $\begin{array}{l}0.06 \\
(0.03)\end{array}$ & $\begin{array}{l}0.19 * * * \\
(0.04)\end{array}$ & $\begin{array}{l}0.13 * * * \\
(0.04)\end{array}$ \\
\hline Blair's Babies & $\begin{array}{l}0.72 * * * \\
(0.09)\end{array}$ & $\begin{array}{l}0.32 * * * \\
(0.06)\end{array}$ & $\begin{array}{l}0.47 * * * \\
(0.07)\end{array}$ & $\begin{array}{l}0.64^{* * * *} \\
(0.06)\end{array}$ & $\begin{array}{l}0.34 * * * \\
(0.07)\end{array}$ & $\begin{array}{l}0.50^{* * * *} \\
(0.07)\end{array}$ & $\begin{array}{l}0.17 * * \\
(0.06)\end{array}$ & $\begin{array}{l}0.21 * * \\
(0.07)\end{array}$ & $\begin{array}{l}0.41 * * * \\
(0.08)\end{array}$ \\
\hline \multicolumn{10}{|c|}{ Age groups (ref.: 34 years and under) } \\
\hline $35-59$ years & $\begin{array}{c}0.08 \\
(0.05)\end{array}$ & $\begin{array}{c}-0.05 \\
(0.04)\end{array}$ & $\begin{array}{c}-0.19 * * * \\
(0.04)\end{array}$ & $\begin{array}{c}-0.02 \\
(0.03)\end{array}$ & $\begin{array}{c}-0.21 * * * \\
(0.04)\end{array}$ & $\begin{array}{c}-0.06 \\
(0.04)\end{array}$ & $\begin{array}{c}-0.07^{*} \\
(0.04)\end{array}$ & $\begin{array}{c}-0.10 * \\
(0.04)\end{array}$ & $\begin{array}{c}0.09 * \\
(0.04)\end{array}$ \\
\hline 60 years and over & $\begin{array}{c}0.03 \\
(0.09)\end{array}$ & $\begin{array}{l}-0.17 * * \\
(0.06)\end{array}$ & $\begin{array}{l}-0.30 * * * \\
(0.07)\end{array}$ & $\begin{array}{l}0.20^{* * *} * \\
(0.06)\end{array}$ & $\begin{array}{c}-0.07 \\
(0.07)\end{array}$ & $\begin{array}{l}0.25^{* * *} * \\
(0.07)\end{array}$ & $\begin{array}{c}-0.10 \\
(0.06)\end{array}$ & $\begin{array}{c}-0.04 \\
(0.08)\end{array}$ & $\begin{array}{c}0.18^{*} \\
(0.08)\end{array}$ \\
\hline Year of survey & $\begin{array}{c}0.00 \\
(0.00)\end{array}$ & $\begin{array}{l}0.02 * * * \\
(0.00)\end{array}$ & $\begin{array}{l}0.04 * * * \\
(0.00)\end{array}$ & $\begin{array}{l}0.07 * * * \\
(0.00)\end{array}$ & $\begin{array}{l}0.07 * * * \\
(0.00)\end{array}$ & $\begin{array}{l}0.07 * * * \\
(0.00)\end{array}$ & $\begin{array}{l}-0.02 * * * \\
(0.00)\end{array}$ & $\begin{array}{l}0.04 * * * \\
(0.00)\end{array}$ & $\begin{array}{l}0.01 * * * \\
(0.00)\end{array}$ \\
\hline Gender (male) & $\begin{array}{l}0.15^{* * * *} \\
(0.04)\end{array}$ & $\begin{array}{l}-0.13^{* * * *} \\
(0.02)\end{array}$ & $\begin{array}{c}0.01 \\
(0.03)\end{array}$ & $\begin{array}{l}-0.21^{* * * *} \\
(0.02)\end{array}$ & $\begin{array}{l}-0.16^{* * * *} \\
(0.03)\end{array}$ & $\begin{array}{c}-0.03 \\
(0.03)\end{array}$ & $\begin{array}{l}0.33^{* * * *} \\
(0.02)\end{array}$ & $\begin{array}{l}-0.16^{* * * *} \\
(0.03)\end{array}$ & $\begin{array}{l}0.14 * * * \\
(0.03)\end{array}$ \\
\hline Education 19 years + & $\begin{array}{l}-0.15^{* * *} \\
(0.04)\end{array}$ & $\begin{array}{l}-0.28 * * * \\
(0.03)\end{array}$ & $\begin{array}{l}-0.12^{* * *} \\
(0.03)\end{array}$ & $\begin{array}{l}-0.40 * * * \\
(0.03)\end{array}$ & $\begin{array}{l}-0.49 * * * \\
(0.03)\end{array}$ & $\begin{array}{l}-0.48 * * * \\
(0.03)\end{array}$ & $\begin{array}{l}-0.89 * * * \\
(0.03)\end{array}$ & $\begin{array}{l}-0.81 * * * \\
(0.03)\end{array}$ & $\begin{array}{l}-0.50 * * * \\
(0.03)\end{array}$ \\
\hline \multicolumn{10}{|l|}{ Marital status (ref.: married) } \\
\hline Previously married & $\begin{array}{l}0.13 * * \\
(0.04)\end{array}$ & $\begin{array}{c}-0.03 \\
(0.03)\end{array}$ & $\begin{array}{c}-0.08^{*} \\
(0.03)\end{array}$ & $\begin{array}{c}-0.07 * * \\
(0.03)\end{array}$ & $\begin{array}{c}-0.04 \\
(0.03)\end{array}$ & $\begin{array}{c}-0.09^{* *} \\
(0.03)\end{array}$ & $\begin{array}{c}-0.18^{* * *} \\
(0.03)\end{array}$ & $\begin{array}{c}-0.25^{* * *} \\
(0.03)\end{array}$ & $\begin{array}{c}-0.20 * * * \\
(0.04)\end{array}$ \\
\hline Single (never married) & $\begin{array}{c}0.05 \\
(0.05)\end{array}$ & $\begin{array}{c}-0.04 \\
(0.03)\end{array}$ & $\begin{array}{c}-0.08^{*} \\
(0.04)\end{array}$ & $\begin{array}{l}-0.31 * * * \\
(0.03)\end{array}$ & $\begin{array}{l}-0.15^{* * *} \\
(0.03)\end{array}$ & $\begin{array}{l}-0.18 * * * \\
(0.03)\end{array}$ & $\begin{array}{l}-0.42 * * * \\
(0.03)\end{array}$ & $\begin{array}{l}-0.46^{* * * *} \\
(0.03)\end{array}$ & $\begin{array}{l}-0.35^{* * * *} \\
(0.04)\end{array}$ \\
\hline \multicolumn{10}{|c|}{ Employment status (ref.: employed FT) } \\
\hline Employed PT & $\begin{array}{c}-0.05 \\
(0.05)\end{array}$ & $\begin{array}{c}-0.03 \\
(0.04)\end{array}$ & $\begin{array}{c}-0.03 \\
(0.04)\end{array}$ & $\begin{array}{c}-0.10^{* *} \\
(0.03)\end{array}$ & $\begin{array}{c}-0.18^{* * * *} \\
(0.04)\end{array}$ & $\begin{array}{c}-0.17^{* * *} \\
(0.04)\end{array}$ & $\begin{array}{c}-0.16^{* * *} \\
(0.03)\end{array}$ & $\begin{array}{l}-0.18^{* * * *} \\
(0.04)\end{array}$ & $\begin{array}{c}-0.12 * * \\
(0.04)\end{array}$ \\
\hline Unemployed/waiting for work & $\begin{array}{c}0.18^{*} \\
(0.07)\end{array}$ & $\begin{array}{c}-0.16^{* *} \\
(0.06)\end{array}$ & $\begin{array}{l}-0.48^{* * * *} \\
(0.07)\end{array}$ & $\begin{array}{l}-1.04 * * * \\
(0.06)\end{array}$ & $\begin{array}{l}-0.93 * * * \\
(0.06)\end{array}$ & $\begin{array}{l}-0.92^{* * * *} \\
(0.06)\end{array}$ & $\begin{array}{l}-0.26^{* * * *} \\
(0.05)\end{array}$ & $\begin{array}{l}-0.47 * * * \\
(0.06)\end{array}$ & $\begin{array}{l}-0.29 * * * \\
(0.06)\end{array}$ \\
\hline Education & $\begin{array}{c}-0.34 \\
(0.23)\end{array}$ & $\begin{array}{c}-0.17 \\
(0.13)\end{array}$ & $\begin{array}{c}-0.41^{* *} \\
(0.15)\end{array}$ & $\begin{array}{l}-0.45^{* * * *} \\
(0.12)\end{array}$ & $\begin{array}{l}-0.47 * * * \\
(0.13)\end{array}$ & $\begin{array}{c}-0.36^{* *} \\
(0.13)\end{array}$ & $\begin{array}{l}-0.63 * * * \\
(0.11)\end{array}$ & $\begin{array}{l}-0.74 * * * \\
(0.12)\end{array}$ & $\begin{array}{l}-0.62 * * * \\
(0.12)\end{array}$ \\
\hline Retired & $\begin{array}{c}0.09 \\
(0.07)\end{array}$ & $\begin{array}{c}0.05 \\
(0.05)\end{array}$ & $\begin{array}{l}-0.19^{* * *} \\
(0.06)\end{array}$ & $\begin{array}{l}-0.21 * * * \\
(0.04)\end{array}$ & $\begin{array}{l}-0.41^{* * *} \\
(0.05)\end{array}$ & $\begin{array}{l}-0.26^{* * *} \\
(0.05)\end{array}$ & $\begin{array}{l}-0.17 * * * \\
(0.05)\end{array}$ & $\begin{array}{c}-0.12 * \\
(0.06)\end{array}$ & $\begin{array}{c}-0.05 \\
(0.07)\end{array}$ \\
\hline Looking after home & $\begin{array}{l}0.22 * * * \\
(0.06)\end{array}$ & $\begin{array}{c}-0.10^{*} \\
(0.04)\end{array}$ & $\begin{array}{l}-0.34 * * * \\
(0.05)\end{array}$ & $\begin{array}{l}-0.40^{* * * *} \\
(0.04)\end{array}$ & $\begin{array}{l}-0.53 * * * \\
(0.04)\end{array}$ & $\begin{array}{l}-0.42 * * * \\
(0.04)\end{array}$ & $\begin{array}{c}-0.11^{* *} \\
(0.04)\end{array}$ & $\begin{array}{l}-0.19^{* * * *} \\
(0.05)\end{array}$ & $\begin{array}{c}-0.14 * * \\
(0.05)\end{array}$ \\
\hline Other employment situation & $\begin{array}{c}-0.08 \\
(0.08)\end{array}$ & $\begin{array}{l}-0.21 * * * \\
(0.05)\end{array}$ & $\begin{array}{l}-0.62 * * * \\
(0.07)\end{array}$ & $\begin{array}{l}-0.77 * * * \\
(0.05)\end{array}$ & $\begin{array}{l}-0.67 * * * \\
(0.05)\end{array}$ & $\begin{array}{l}-0.79 * * * \\
(0.06)\end{array}$ & $\begin{array}{l}-0.03 \\
(0.05)\end{array}$ & $\begin{array}{c}-0.13^{*} \\
(0.06)\end{array}$ & $\begin{array}{c}-0.03 \\
(0.07)\end{array}$ \\
\hline
\end{tabular}


TABLE 3 (Continued)

\begin{tabular}{|c|c|c|c|c|c|c|c|c|c|}
\hline & $\begin{array}{l}\text { (1) } \\
\text { Income gap in } \\
\text { society is too } \\
\text { small or about } \\
\text { right }\end{array}$ & $\begin{array}{c}\text { (2) } \\
\text { Disagree/strongly } \\
\text { disagree: } \\
\text { Government } \\
\text { should redistribute }\end{array}$ & $\begin{array}{l}\text { (3) } \\
\text { Disagree/strongly } \\
\text { disagree: Government } \\
\text { should spend more to } \\
\text { help poor }\end{array}$ & $\begin{array}{l}\text { Benefits too } \\
\text { high and } \\
\text { discourage } \\
\text { job search }\end{array}$ & $\begin{array}{l}\text { Unemployed } \\
\text { could find a } \\
\text { job if they } \\
\text { wanted }\end{array}$ & $\begin{array}{l}\text { People should } \\
\text { learn to stand on } \\
\text { their own two } \\
\text { feet }\end{array}$ & $\begin{array}{l}\text { Death penalty } \\
\text { is appropriate } \\
\text { for certain } \\
\text { crimes }\end{array}$ & $\begin{array}{c}(8) \\
\text { Stiffer } \\
\text { sentences } \\
\text { for } \\
\text { breaking } \\
\text { the law }\end{array}$ & $\begin{array}{l}\text { Children } \\
\text { should be } \\
\text { taught to obey } \\
\text { authority }\end{array}$ \\
\hline \multicolumn{10}{|l|}{ Household income (ref.: low) } \\
\hline Mid & $\begin{array}{l}0.12 * * \\
(0.04)\end{array}$ & $\begin{array}{l}0.30 * * * \\
(0.03)\end{array}$ & $\begin{array}{l}0.26 * * * \\
(0.04)\end{array}$ & $\begin{array}{l}0.22 * * * \\
(0.03)\end{array}$ & $\begin{array}{l}0.16^{* * * *} \\
(0.03)\end{array}$ & $\begin{array}{l}0.14 * * * \\
(0.03)\end{array}$ & $\begin{array}{l}-0.18 * * * \\
(0.03)\end{array}$ & $\begin{array}{l}-0.17 * * * \\
(0.04)\end{array}$ & $\begin{array}{l}-0.18^{* * * *} \\
(0.04)\end{array}$ \\
\hline High & $\begin{array}{l}0.68 * * * \\
(0.06)\end{array}$ & $\begin{array}{l}0.71 * * * \\
(0.04)\end{array}$ & $\begin{array}{l}0.32^{* * *} \\
(0.05)\end{array}$ & $\begin{array}{l}0.28^{* * * *} \\
(0.04)\end{array}$ & $\begin{array}{l}0.36 * * * \\
(0.04)\end{array}$ & $\begin{array}{l}0.16^{* * * *} \\
(0.04)\end{array}$ & $\begin{array}{l}-0.35^{* * * *} \\
(0.04)\end{array}$ & $\begin{array}{l}-0.38 * * * \\
(0.05)\end{array}$ & $\begin{array}{l}-0.33 * * * \\
(0.05)\end{array}$ \\
\hline Attended private school & $\begin{array}{l}0.16 * * * \\
(0.04)\end{array}$ & $\begin{array}{l}0.11 * * * \\
(0.03)\end{array}$ & $\begin{array}{c}-0.05 \\
(0.04)\end{array}$ & $\begin{array}{l}-0.11 * * * \\
(0.03)\end{array}$ & $\begin{array}{l}-0.11 * * \\
(0.04)\end{array}$ & $\begin{array}{l}-0.20 * * * \\
(0.04)\end{array}$ & $\begin{array}{l}-0.30 * * * \\
(0.03)\end{array}$ & $\begin{array}{l}-0.38 * * * \\
(0.04)\end{array}$ & $\begin{array}{c}-0.07 \\
(0.04)\end{array}$ \\
\hline Owns house & $\begin{array}{c}-0.02 \\
(0.04)\end{array}$ & $\begin{array}{l}0.30 * * * \\
(0.03)\end{array}$ & $\begin{array}{l}0.26 * * * \\
(0.03)\end{array}$ & $\begin{array}{l}0.25^{* * *} * \\
(0.02)\end{array}$ & $\begin{array}{c}-0.02 \\
(0.03)\end{array}$ & $\begin{array}{l}0.15^{* * * *} \\
(0.03)\end{array}$ & $\begin{array}{l}-0.11 * * * \\
(0.03)\end{array}$ & $\begin{array}{c}0.01 \\
(0.03)\end{array}$ & $\begin{array}{l}0.17 * * * \\
(0.03)\end{array}$ \\
\hline Union member & $\begin{array}{l}-0.28 * * * \\
(0.04)\end{array}$ & $\begin{array}{l}-0.19 * * * \\
(0.03)\end{array}$ & $\begin{array}{c}-0.09 * * \\
(0.03)\end{array}$ & $\begin{array}{l}-0.19 * * * \\
(0.02)\end{array}$ & $\begin{array}{l}-0.29 * * * \\
(0.03)\end{array}$ & $\begin{array}{l}-0.18^{* * * *} \\
(0.03)\end{array}$ & $\begin{array}{l}-0.10 * * * \\
(0.03)\end{array}$ & $\begin{array}{c}-0.06^{*} \\
(0.03)\end{array}$ & $\begin{array}{l}-0.21 * * * \\
(0.03)\end{array}$ \\
\hline \multicolumn{10}{|l|}{ Social class (ref.: Class I) } \\
\hline Class II & $\begin{array}{l}-0.20 * * \\
(0.07)\end{array}$ & $\begin{array}{l}0.14 * * \\
(0.05)\end{array}$ & $\begin{array}{l}-0.05 \\
(0.05)\end{array}$ & $\begin{array}{l}0.14 * * \\
(0.05)\end{array}$ & $\begin{array}{l}0.15^{* *} \\
(0.05)\end{array}$ & $\begin{array}{l}0.16^{* *} \\
(0.06)\end{array}$ & $\begin{array}{c}0.11^{*} \\
(0.05)\end{array}$ & $\begin{array}{l}0.22 * * * \\
(0.05)\end{array}$ & $\begin{array}{c}-0.04 \\
(0.06)\end{array}$ \\
\hline Class III M & $\begin{array}{l}-0.29 * * * \\
(0.07)\end{array}$ & $\begin{array}{c}0.03 \\
(0.05)\end{array}$ & $\begin{array}{c}-0.01 \\
(0.06)\end{array}$ & $\begin{array}{l}0.23 * * * \\
(0.05)\end{array}$ & $\begin{array}{l}0.30 * * * \\
(0.06)\end{array}$ & $\begin{array}{l}0.35^{* * * *} \\
(0.06)\end{array}$ & $\begin{array}{l}0.42 * * * \\
(0.05)\end{array}$ & $\begin{array}{l}0.62 * * * \\
(0.05)\end{array}$ & $\begin{array}{l}0.31 * * * \\
(0.06)\end{array}$ \\
\hline Class III NM & $\begin{array}{l}-0.38^{* * *} \\
(0.07)\end{array}$ & $\begin{array}{c}-0.09 \\
(0.05)\end{array}$ & $\begin{array}{c}-0.02 \\
(0.06)\end{array}$ & $\begin{array}{l}0.26 * * * \\
(0.05)\end{array}$ & $\begin{array}{l}0.51 * * * \\
(0.06)\end{array}$ & $\begin{array}{l}0.52 * * * \\
(0.06)\end{array}$ & $\begin{array}{l}0.76^{* * *} \\
(0.05)\end{array}$ & $\begin{array}{l}0.82 * * * \\
(0.06)\end{array}$ & $\begin{array}{l}0.41 * * * \\
(0.07)\end{array}$ \\
\hline Class IV & $\begin{array}{c}-0.20^{*} \\
(0.08)\end{array}$ & $\begin{array}{l}-0.26^{* * * *} \\
(0.06)\end{array}$ & $\begin{array}{c}-0.06 \\
(0.06)\end{array}$ & $\begin{array}{l}0.20 * * * \\
(0.05)\end{array}$ & $\begin{array}{l}0.45^{* * * *} \\
(0.06)\end{array}$ & $\begin{array}{l}0.48 * * * \\
(0.06)\end{array}$ & $\begin{array}{l}0.61 * * * \\
(0.05)\end{array}$ & $\begin{array}{l}0.81 * * * \\
(0.06)\end{array}$ & $\begin{array}{l}0.32 * * * \\
(0.07)\end{array}$ \\
\hline Class V & $\begin{array}{c}-0.00 \\
(0.09)\end{array}$ & $\begin{array}{l}-0.30^{* * *} \\
(0.07)\end{array}$ & $\begin{array}{c}-0.14 \\
(0.08)\end{array}$ & $\begin{array}{l}0.17 * * \\
(0.06)\end{array}$ & $\begin{array}{l}0.49 * * * \\
(0.07)\end{array}$ & $\begin{array}{l}0.56^{* * *} * \\
(0.07)\end{array}$ & $\begin{array}{l}0.72 * * * \\
(0.07)\end{array}$ & $\begin{array}{l}0.75 * * * \\
(0.08)\end{array}$ & $\begin{array}{l}0.32 * * * \\
(0.09)\end{array}$ \\
\hline $\begin{array}{l}\text { Conservative Party } \\
\text { identification }\end{array}$ & $0.93 * * *$ & $1.12 * * *$ & $0.84 * * *$ & $0.86^{* * *}$ & $0.63^{* * *}$ & $0.80^{* * *}$ & $0.60 * * *$ & $0.71 * * *$ & $0.78 * * *$ \\
\hline & $(0.03)$ & $(0.02)$ & $(0.03)$ & $(0.02)$ & $(0.02)$ & $(0.02)$ & $(0.02)$ & $(0.03)$ & $(0.03)$ \\
\hline Constant & $\begin{array}{c}-9.02 \\
(5.16)\end{array}$ & $\begin{array}{c}-46.50 * * * \\
(3.87)\end{array}$ & $\begin{array}{c}-89.69 * * * \\
(4.80)\end{array}$ & $\begin{array}{c}-131.83 * * * \\
(3.65)\end{array}$ & $\begin{array}{c}-149.17 * * * \\
(4.34)\end{array}$ & $\begin{array}{c}-148.89 * * * \\
(4.48)\end{array}$ & $\begin{array}{l}48.78 * * * \\
(3.92)\end{array}$ & $\begin{array}{c}-71.78 * * * \\
(4.65)\end{array}$ & $\begin{array}{c}-24.82 * * * \\
(5.09)\end{array}$ \\
\hline$N$ & 33,848 & 48,399 & 39,029 & 48,817 & 39,052 & 39,036 & 46,613 & 46,651 & 46,596 \\
\hline Pseudo $R^{2}$ & 0.054 & 0.089 & 0.069 & 0.095 & 0.072 & 0.093 & 0.083 & 0.085 & 0.068 \\
\hline Log likelihood & $-14,775.56$ & $-28,119.20$ & $-21,080.37$ & $-30,145.42$ & $-24,963.98$ & $-23,846.78$ & $-28,395.55$ & $-21,595.10$ & $-18,872.24$ \\
\hline
\end{tabular}

Note: standard errors in parentheses. ${ }^{*} \mathrm{p}<0.05,{ }^{* *} \mathrm{p}<0.01,{ }^{* * *} \mathrm{p}<0.001$ 
T A B LE $4 \quad$ Wald Tests for Intergenerational Differences from APC Models

\begin{tabular}{|c|c|c|c|c|c|c|c|c|c|}
\hline & $\begin{array}{c}\text { (1) } \\
\text { Income gap in } \\
\text { society is too } \\
\text { small or about } \\
\text { right }\end{array}$ & $\begin{array}{c}(2) \\
\text { Disagree/strongly } \\
\text { disagree: } \\
\text { Government } \\
\text { should } \\
\text { redistribute }\end{array}$ & $\begin{array}{c}(3) \\
\text { Disagree/strongly } \\
\text { disagree: } \\
\text { Government should } \\
\text { spend more to help } \\
\text { poor }\end{array}$ & $\begin{array}{c}\text { (4) } \\
\text { Benefits too } \\
\text { high and } \\
\text { discourage } \\
\text { job search }\end{array}$ & $\begin{array}{l}\text { (5) } \\
\text { Unemployed } \\
\text { could find a } \\
\text { job if they } \\
\text { wanted }\end{array}$ & $\begin{array}{c}\text { (6) } \\
\text { People should } \\
\text { learn to stand } \\
\text { on their own } \\
\text { two feet }\end{array}$ & $\begin{array}{l}\text { (7) } \\
\text { Death penalty } \\
\text { is appropriate } \\
\text { for certain } \\
\text { crimes }\end{array}$ & $\begin{array}{c}(8) \\
\text { Stiffer } \\
\text { sentences } \\
\text { for } \\
\text { breaking } \\
\text { the law }\end{array}$ & $\begin{array}{l}\text { (9) } \\
\text { Children } \\
\text { should be } \\
\text { taught to } \\
\text { obey } \\
\text { authority }\end{array}$ \\
\hline Pre-consensus generation = early consensus generation & ** & ns & ns & $* * *$ & ns & $* * *$ & ns & $* * *$ & $* * *$ \\
\hline Pre-consensus generation $=$ Thatcher's Children & $\mathrm{ns}$ & $\mathrm{ns}$ & $* * *$ & $* * *$ & $\mathrm{~ns}$ & $* * *$ & ns & $* * *$ & $* * *$ \\
\hline Early consensus generation $=$ Thatcher's Children & ns & ns & $* * *$ & ns & ns & $* * *$ & ns & ns & *** \\
\hline Thatcher's Children = Blair's Babies & $* * *$ & $* * *$ & $\mathrm{~ns}$ & $* * *$ & $* *$ & $* * *$ & ** & $\mathrm{ns}$ & $* * *$ \\
\hline Pre-consensus generation = Blair's Babies & $* *$ & ns & *** & ns & ns & $* * *$ & ns & * & *** \\
\hline Early consensus generation $=$ Blair's Babies & $* * *$ & $*$ & $* * *$ & $* * *$ & * & ns & ns & ns & ns \\
\hline
\end{tabular}

Note: a significant result implies cohort differences between each given pair in the rows for each of the dependent variables in the columns. See coefficients in Table 3 for direction of effects. *p $<0.05$, **p $<0.01$, ***p $<0.001$ 
than the middle class to agree that government should redistribute. However, there are no class differences for the survey item that suggests a trade-off between redistribution and taxation. Interestingly, controlling for all other variables in the models, all three items on benefits and all three items on authoritarianism show that all other classes are more likely to agree with the Thatcherite tendency than the upper middle class, which supports the populist story line.

Turning to the APC results, first it should be noted that there are some small age effects: the middle age group is more likely than the younger group to support redistribution if it entails higher taxes, to express more positive views of the unemployed and to disagree that the death penalty is appropriate for some crimes. Those in the oldest age group are less likely to agree with the Thatcherite position on redistribution than the youngest age group, but are more likely to think poorly of benefit seekers and to want children to be taught to obey authority. The effects for year of survey show that, with the exception of the inequality item, there are significant period effects with increasing support for the Thatcherite position in all cases except support for the death penalty. This suggests that, over a period of twenty or more years, the electorate indeed became more Thatcherite, particularly with respect to negative attitudes about the benefits system, the unemployed, benefit recipients and the welfare system more generally.

The coefficients for political generations in the APC models presented in Table 3, in conjunction with the results from the Wald tests presented in Table 4, show that across eight of nine indicators, Thatcher's Children are more right wing and authoritarian than the generation preceding them (Wilson/Callaghan's Children). This provides support to Hypothesis 1. Blair's Babies are also more right wing and authoritarian than this political generation, confirming that Thatcherite values were reproduced under New Labour, and become stronger and embedded in the generation that came of age after Thatcher's time in office. This is consistent with Hypothesis 2. Thatcher's Children and Blair's Babies are even more right wing economically than the generation that came of age before the post-war consensus. Blair's Babies in particular are almost as negative about benefits and the welfare system as the generation that came of age before it was created. They are also nearly as authoritarian as the oldest generations, showing that the trend toward modernization and greater social liberalism was at least slowed down in Britain under the Thatcher governments.

As explained in the data and methods section, in order to provide robustness tests for the results from the APC models, we next examine the visual results from the GAMs. In particular, we examine the plots of the smoothed cohort effect from the full model (not shown) with the same controls included as in the APC models. These plots are presented in Figure 1-9. ${ }^{55}$

The patterns are striking and consistent. Across the plots for the smoothed cohort effects all nine indicators, there is an upward swing in right-authoritarian values from around the start of the years of birth of the Thatcherite political generation (that is, those born in 1959) at least up until the end of it (those born in 1976), and in several cases lasting well beyond. This suggests Thatcherite values were growing in strength among the cohort that became political adults during the Thatcher years. With the exception of two of the nine figures, one can see an upswing during the birth years of Thatcher's Children, thus reversing the trend towards greater support for redistribution and social egalitarianism observed for previous political generations (the cohorts born before 1959). This provides clear support for the theoretical expectation of a 'Thatcher effect' (Hypothesis 1). It is especially noticeable that the curve bends upwards and commences the increasing trend precisely at the end of the 1950s (the birth years of the oldest of Thatcher's Children).

\footnotetext{
55 The smoothed term is always highly significant. As standard, we judge the significance through the edf value. A value greater than 1 suggests significance and that smoothing should be applied.
} 

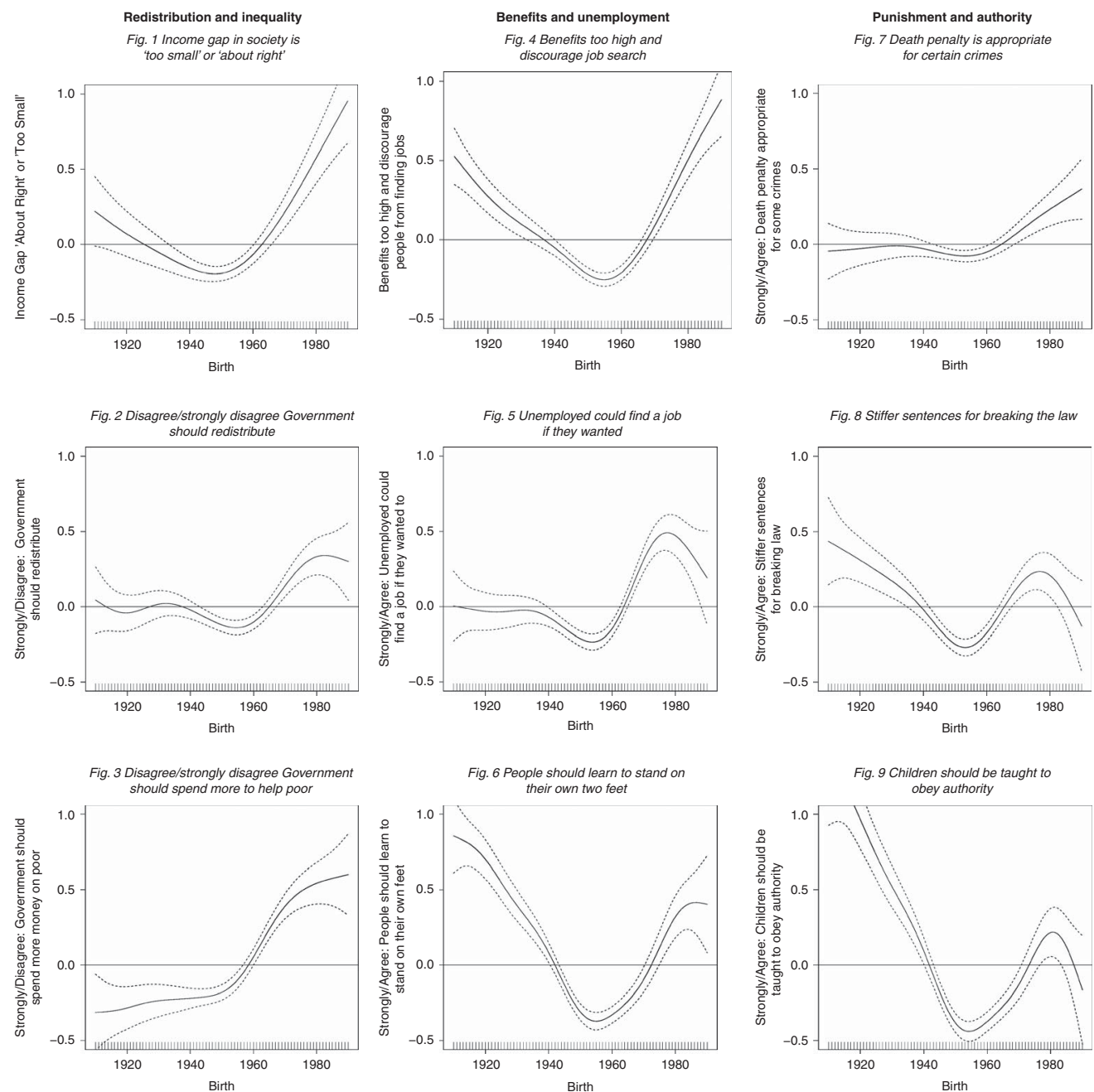

Fig. 1-9. Smoothed cohort effects from generalized additive models (GAMs).

While the curve during the birth years of Thatcher's Children does not always return to the levels of the pre- and early consensus generations, there is a tendency towards greater conservatism that starts with Thatcher's Children (those born 1959-76) across all nine indicators. With respect to the political generation born between 1977 and 1990 (that is, Blair's Babies or Thatcher's Grandchildren), we find that in some cases the upward trend continues, for example on the income gap between rich and poor (Figure 1) and the beliefs that benefits are too high (Figure 4) and that the death penalty is appropriate for some crimes (Figure 7). In other cases, however, there is a counter-tendency and it looks like the trend might level off or even reverse, such as for whether people who break the law should be given stiffer sentences (Figure 9), although the confidence intervals are typically too wide to be certain at the time of writing. More years of data are needed to clarify trends in social values among the youngest members of this new political generation. Regardless, with respect to attitudes on redistribution (Figures 1-3) the curve ends at a higher point than its level during the birth years of the pre- and 
early consensus generations, providing evidence that Blair's Babies are a distinctly right-wing cohort in their economic values, which is consistent with Hypothesis 2. Moreover, with respect to authoritarian values, Thatcher's Children exhibit a slowing down and reversal of the modernization tendency towards greater social liberalism, which is consistent with Hypothesis 2. In particular, with respect to support for inequality, redistribution and particularly redistribution versus taxation, but also attitudes towards the unemployed/benefits, Thatcher's Children and Blair's Babies are more right wing than any of the three older generations. This provides considerable support for our theoretical expectations.

We thus find mixed support for each hypothesis. With respect to the first hypothesis, the results confirm that Thatcher's Children are indeed more right wing and authoritarian than the generation preceding them, the more liberal Wilson/Callaghan's Children. This is true when we examine eight out of nine attitudinal variables capturing different dimensions of Thatcherite beliefs. Thatcher's period in office reversed the generational trend in social values. With respect to the second hypothesis, we find evidence that Blair's Babies are also more right wing and authoritarian than Wilson/Callaghan's Children. They are also more economically right wing than both the pre- and early consensus generations, but not more socially authoritarian than either. Overall then, Blair's Babies stand out as the most economically right-wing generation; they are also more authoritarian than Thatcher's Children. Our models thus show that the generation coming of age in the aftermath of the Cold War, once Thatcher had left office, stands out as the most economically conservative, net of both period and age effects. Overall, the results provide some support for the idea of a political generation of 'Thatcher's Children', since with this cohort we see a reversal of the trend towards greater social liberalism and support for redistribution. These results also suggest that rendering Thatcherite values uncontentious (under Blair) was more significant for ensuring their long-term endurance.

To test whether it was Labour Party identifiers in particular who moved to the right under Blair, ${ }^{56}$ we included an interaction effect of Labour Party identification with Blair's Babies. This interaction effect was significant for the three redistribution and inequality indicators as well as for the three welfare items. However, this was not the case for the three authoritarian values indicators. These results therefore show that it was the generation coming of age under New Labour and identifying with this party that moved to the right. This further strengthens the conclusion that Blair achieved more than Thatcher had done in terms of cementing her principles in British society, and that this was achieved through Labour supporters embracing more right-wing positions as these became mainstream and uncontested in society. ${ }^{57} \mathrm{We}$ also ran a series of interaction tests with various socio-demographic and regional variables that showed that the generational differences were generally consistent across groups. ${ }^{58}$

${ }^{56}$ Curtice and Fisher 2003.

${ }^{57}$ Curtice and Fisher 2003.

${ }^{58}$ We tested interaction effects with class and union membership across models, but could not find any systematic patterns; our overall results are robust to these additional analyses. There was limited evidence for the survey items 'Government should spend more money to help poor' and 'Benefits too high and discourage job search', and the generation gap was smaller among individuals in unskilled manual occupations relative to individuals in the highest professional class. Similarly, being a union member among Blair's Babies narrowed the gap in values with the Wilson/Callaghan generation. The only items for which there was variation across regions were those on unemployment and benefits ('Benefits too high and discourage job search', 'Unemployed could find a job if they wanted' and 'People should learn to stand on their own two feet'); all other regions were more right wing than Scotland, but the results for generation effects remained unchanged. Testing for interaction effects between region and generation showed that this regional gap was narrower for younger cohorts. 


\section{CONCLUSIONS}

The results presented in this article offer strong evidence of cohort effects. We have shown that generations coming of age under sustained periods of Conservative government absorb these values, offsetting the tendency towards social liberalism that is normally characteristic of youth. More specifically, since we examined British data, we showed that the generation that came of political age during Thatcher and Major's time in office is particularly conservative, and deserving of the epithet 'Thatcher's Children'. But we have not just found more evidence of 'Thatcher's Children'; we have also discovered her 'Grandchildren' in 'Blair's Babies'.

We analysed indicators of Thatcherite values across three dimensions - redistribution and inequality, benefits and unemployment, punishment and authority - and found that this generation (born between 1959 and 1976) reversed the cohort trend towards greater support for redistribution and more social liberalism. This pattern is largely continued in the subsequent generation of Thatcher's Grandchildren, which supports the idea that Thatcherite values were reproduced, not challenged, under New Labour ${ }^{59}$. Our analyses showed that Blair's Babies are even more right-authoritarian. It seems that the trend towards ever-greater social liberalism was halted and even reversed, supporting the idea that Thatcherism has fundamentally changed British social attitudes in an enduring way. The timing of the upward trend in the GAMsmoothed cohort effect plots coincided with the birth years of Thatcher's Children. This occurs at the same time across indicators. By disentangling APC effects using new statistical techniques and analysing a long time series of attitudinal data, we have shown that Thatcher's crusade successfully promoted and consolidated economic as well as social values. Her moral crusade was extremely successful at changing the values of the generation that came of age at that time, and at influencing society to such an extent that New Labour came to accept these as setting the ideational parameters of political competition.

How these trends in social values unfold will also be enlightening, and only time will tell whether the fragmentation of the British party system, fallout from the economic crisis, the era of austerity and the outcome of the referendum on Britain's membership of the European Union will influence these trajectories. These results may also be relevant to other countries that have experienced protracted periods of conservative rule and where the New Right was popular, such as Canada, Australia, New Zealand and the United States. ${ }^{60}$ It is likely that comparable political environments will have had similarly formative impacts on newer political generations. There are implications for modernization theory and for what sorts of events might provide countertendencies to the 'inexorable logic' of greater tolerance and social liberalism.

Most importantly, this article shows that particularly significant events such as the protracted rule of one party followed by a centrist shift towards that party's position from the opposition are important 'formative experiences' for new generations. Moreover, we have also shown that such changes can have spillover effects by reproducing certain values when subsequent governments or parties in power do not challenge the values that formed that generation. This trickle-down theory of social change can explain why Thatcherite attitudes are still more prevalent in 'Blair's Babies' or 'Thatcher's Grandchildren'. This is a clear sign that Thatcher changed the course of British politics and social attitudes. Her values - or the values that have come to be associated with her name permeate British society today as subsequent governments have not challenged her ideology. For better or worse, it seems that we still live in 'Thatcher's Britain'.

59 See also recent work by Temple et al. 2016; English et al. 2016.

60 Duménil and Lévy 2011; Kotz 2015; Swarts 2013. 


\section{REFERENCES}

Bartels, Larry, and Simon Jackman. 2014. A Generational Model of Political Learning. Electoral Studies 33:7-18.

Bartle, John, Sebastian Dellepiane-Avellaneda, and James A. Stimson. 2011. The Moving Centre: Preferences for Government Activity in Britain, 1950-2005. British Journal of Political Science 41 (2):259-85.

Bell, Andrew, and Kelvyn Jones. 2014a. Another 'Futile Quest'? A Simulation Study of Yang and Land's Hierarchical Age-Period-Cohort Model. Demographic Research 30:333-60.

— 2014b. Don't Birth Cohorts Matter? A Commentary and Simulation Exercise on Reither, Hauser, and Yang's (2009) Age-Period-Cohort Study. Social Science \& Medicine 101:176-80.

Braedley, Susan, and Meg Luxton, eds. 2010. Neoliberalism and Everyday Life. Montreal: McGill-Queens University Press.

Coates, David. 2005. Prolonged Labour: The Slow Birth of New Labour Britain. Basingstoke: Palgrave.

Crewe, Ivor. 1988. Has the Electorate Become Thatcherite? In Thatcherism, edited by R. Skidelsky, 24-49. London: Chatto and Windus.

- 1989. Values: The Crusade that Failed. In The Thatcher Effect, edited by D. Kavanagh and A. Seldon. Oxford: The Clarendon Press.

Curtice, John. 2009. Were British Voters Transformed by Thatcherism? British Politics Review 4 (1):7.

— 2010. Thermostat or Weathervane: Public Reactions to Spending and Redistribution Under New Labour. In British Social Attitudes: The 26th Report, edited by A. Park, J. Curtice, K. Thomson and M. Phillips, 19-38. London: Sage.

Curtice, John, and Stephen Fisher. 2003. The Power to Persuade? A Tale of Two Prime Ministers. In British Social Attitudes: the 20th Report: Continuity and Change Over Two Decades, edited by A. Park, 233-54. London: Sage.

Curtice, John, and Roger Jowell. 1997. Trust in the Political System. In British Social Attitudes: The 14th Report. The End of Conservative Values?, edited by R. Jowell, J. Curtice, A. Park and L. Brook. Ashgate: Aldershot.

Duménil, Gérard, and Dominique Lévy. 2011. The Crisis of Neo-liberalism. Cambridge, MA: Harvard University Press.

Dunleavy, Patrick, and Hugh Ward. 1981. Exogenous Voter Preferences and Parties with State Power: Some Internal Problems of Economic Theories of Party Competition. British Journal of Political Science 11 (3):351-80.

Dunn, Andrew, Maria Teresa Grasso, and Clare Saunders. 2014. Unemployment and Attitudes to Work: Asking the 'Right' Question. Work, Employment, and Society 28 (6):904-25.

English, Patrick, Maria T. Grasso, Barbara Buraczynska, Sotirios Karampampas, and Luke Temple. 2016. Convergence on Crisis? Comparing Labour and Conservative Party Framing of the Economic Crisis in Britain, 2008-2014. Politics \& Policy 44 (3):577-603.

Erikson, Robert S., Michael B. Mackuen, and James A. Stimson. 2002. The Macro Polity. Cambridge: Cambridge University Press.

Erikson, Robert, and Laura Stoker. 2011. Caught in the Draft: The Effects of Vietnam Draft Lottery Status on Political Attitudes. American Political Science Review 105 (2):221-37.

Evans, Geoff, and Nan Dirk De Graaf. 1996. Why are the Young More Postmaterialist? A Cross-National Analysis of Individual and Contextual Influences on Postmaterial Values. Comparative Political Studies 28 (4):608-35.

Evans, Geoff, and James Tilley. 2012. The Depoliticization of Inequality and Redistribution: Explaining the Decline of Class Voting. The Journal of Politics 74 (4):963-76.

Farrall, Stephen, and Colin Hay. (eds) 2014. The Legacy of Thatcherism: Exploring and Theorising the Long-term Consequences of Thatcherite Social and Economic Policies. Oxford University Press: Oxford.

— Jonathan Jackson, and Emily Gray. 2009. Social Order and the Fear of Crime in Contemporary Times, Clarendon Studies in Criminology. Oxford University Press: Oxford. 
Faucher-King, Florence, and Patrick Le Galés. 2010. The New Labour Experiment: Change and Reform Under Blair and Brown. Stanford, CA: Stanford University Press.

Gamble, Andrew. 1988. The Free Economy and the Strong State: The Politics of Thatcherism. Basingstoke: Palgrave Macmillan.

Gilroy, Paul, and Joe Simm. 1985. Law, Order and the State of the Left. Capital \& Class 9 (1):15-55.

Giugni, Marco G., and Maria T. Grasso, eds. 2015a. Austerity and Protest: Popular Contention in Times of Economic Crisis. London: Routledge.

Giugni, Marco G., and Maria T. Grasso. 2015b. Environmental Movements in Advanced Industrial Democracies: Heterogeneity, Transformation, and Institutionalization. Annual Review of Environment and Resources 40:337-61.

Giugni, M., and Maria T. Grasso. 2016. How Civil Society Actors Responded to the Economic Crisis: The Interaction of Material Deprivation and Perceptions of Political Opportunity Structures. Politics \& Policy 44 (3):447-72.

Grasso, Maria Teresa. 2011. Political Participation in Western Europe, D.Phil. Thesis, Nuffield College, University of Oxford.

— 2013. The Differential Impact of Education on Young People's Political Activism: Comparing Italy and the United Kingdom. Comparative Sociology 12:1-30.

2014. Age-Period-Cohort Analysis in a Comparative Context: Political Generations and Political Participation Repertoires. Electoral Studies 33:63-76.

2016. Generations, Political Participation and Social Change in Western Europe. London: Routledge.

Grasso, Maria Teresa, and Marco Giugni. 2013. Anti-austerity Movements: Old Wine in New Vessels?" In XXVII Meeting of the Italian Political Science Association, University of Florence, 12-14 September.

Grasso, Maria T., and Marco Giugni. 2016a. Protest Participation and Economic Crisis: The Conditioning Role of Political Opportunities. European Journal of Political Research 55 (4):663-80.

Grasso, Maria Teresa, and Marco Giugni. 2016b. Do Issues Matter? Anti-Austerity Protests' Composition, Values, and Action Repertoires Compared. Research in Social Movements, Conflicts and Change 39:31-58.

Hall, Stuart. 1979. The Great Moving Right Show. Marxism Today, 14-20.

Hay, Colin. 1996. Re-Stating Social and Political Change. Milton Keynes: Open University Press.

2004. The Normalizing Role of Rationalist Assumptions in the Institutional Embedding of Neoliberalism. Economy and Society 33 (4):500-27.

Heath, Anthony, and Alison Park. 1997. Thatcher's Children? In British Social Attitudes: The End of Conservative Values? (The 14th Report), edited by R. Jowell, 1-22. London: Sage.

Heffernan, Richard. 2000. New Labour and Thatcherism. Basingstoke: Macmillan.

Hobsbawm, Eric. 1979. The Forward March of Labour Halted? - A Response. Marxism Today September 1978:265-68.

Inglehart, Ronald. 1977. The Silent Revolution: Changing Values and Political Styles Among Western Publics. Princeton, NJ: Princeton University Press.

1990. Culture Shift in Advanced Industrial Society. Princeton, NJ: Princeton University Press.

Inglehart, Ronald, and Christian Welzel. 2005. Modernization, Cultural Change and Democracy: The Human Development Sequence. Cambridge, UK: Cambridge University Press.

Jennings, Will, Emily Gray, Colin Hay, and Stephen Farrall. 2015. Collating Longitudinal Data on Crime, Victimization and Social Attitudes in England and Wales: A New Resource for Exploring LongTerm Trends in Crime. British Journal of Criminology 55 (5):1005-015.

Kotz, David M. 2015. The Rise and Fall of Neoliberal Capitalism. Cambridge, MA: Harvard University Press.

Mannheim, Karl. 1928. The Problem of Generations, In Essays on the Sociology of Knowledge, 276-320. London: Routledge.

Neundorf, Anja. 2010. Democracy in Transition: A Micro Perspective on System Change in Post-Socialist Societies. Journal of Politics 72 (4):1096-108.

Neundorf, Anja, and Richard G. Niemi. 2014. Beyond Political Socialization: New Approaches to Age, Period, Cohort Analysis. Electoral Studies 33:1-6. 
Russell, Andrew T., Ron J. Johnston, and Charles J. Pattie. 1992. Thatcher's Children: Exploring the Links Between Age and Political Attitudes. Political Studies 40 (4):742-56.

Saunders, Clare, Maria Teresa Grasso, Cristiana Olcese, Emily Rainsford, and Christopher Rootes. 2012. Explaining Differential Protest Participation: Novices, Returners, Repeaters and Stalwarts. Mobilization 17 (3):263-80.

Shaw, Eric. 2008. Losing Labour's Soul?: New Labour and the Blair Government 1997-2007. London: Routledge.

Shorrocks, Rosalind. 2016. Modernisation and Government Socialisation: Considering Explanations for Gender Differences in Cohort Trends in British Voting Behaviour. Electoral Studies 42:237-48.

Sowell, Thomas. 2012. Trickle Down Theory and Tax Cuts for the Rich. Stanford, CA: Hoover Institution Press.

Swarts, Jonathan. 2013. Constructing Neoliberalism: Economic Transformation in Anglo-American Democracies. Toronto: University of Toronto Press.

Temple, Luke, Grasso, Maria T., Buraczynska, Barbara, Karampampas, Sotirios, and English, Patrick. 2016. Neoliberal Narrative in Times of Economic Crisis: A Political Claims Analysis of the UK Press, 2007-2014. Politics \& Policy 44 (3):553-76.

Tilley, James. 2001. Social and Political Generations in Contemporary Britain, D.Phil. Thesis, Nuffield College, University of Oxford.

2002. Political Generations and Partisanship in the UK, 1964-1997. Journal of the Royal Statistical Society, Series A (Statistics in Society) 165 (1):121-35.

2003. Party Identification in Britain: Does Length of Time in the Electorate Affect Strength of Partisanship? British Journal of Political Science 33 (2):332-44.

2005. Libertarian-Authoritarian Value Change in Britain, 1974-2001. Political Studies 53 (2): $442-453$.

Tilley, James, and Geoff Evans. 2014. Ageing and Generational Effects on Vote Choice. Electoral Studies 33:19-27.

Tilley, James, and Anthony Heath. 2007. The Decline of British National Pride. British Journal of Sociology 58 (4):661-78.

Wlezien, Christopher. 1995. The Public as Thermostat: Dynamics of Preferences for Spending. American Journal of Political Science 39 (4):981-1000.

Yang, Yang, and Kenneth Land. 2006. A Mixed Models Approach to the Age-Period-Cohort Analysis of Repeated Cross-Section Surveys, With an Application to Data on Trends in Verbal Test Scores. Sociological Methodology 36 (1):75-97.

- 2008. Age-Period-Cohort Analysis of Repeated Cross-Section Surveys: Fixed or Random Effects? Sociological Methods \& Research 36 (3):297-326.

Yang, Yang, Sam Schulhofer-Wohl, Wenjiang Fu, and Kenneth Land. 2008. The Intrinsic Estimator for Age-Period-Cohort Analysis: What it is and How to Use it. American Journal of Sociology 113 (6):1697-736. 